\title{
Trainmasters or Easyjet pilots? Historical production, labor organizing, and the Spanish engine drivers' union
}

\author{
Natalia Buier ${ }^{1}$
}

Published online: 8 May 2018

(C) The Author(s) 2018

\begin{abstract}
This article presents an analysis of the relationship between historical memory and the emergence and reproduction of a specific model of unionism. I argue that in order to understand the militant particularism of the Spanish engine drivers, we need to look at the historical representations that it is embedded in. Recourse to a generational framework makes possible the sustained presentation of the union as a case of successful workers' organizing, in spite of evidence to the contrary. The historical ethnographic analysis of SEMAF, the Spanish engine drivers' union, contributes to the analysis of historical memory within the contemporary anthropology of class. The article contributes to theoretical debates in the anthropology of class by reclaiming Michel Trouillot's conceptualization of the historical process. Two aspects of Trouillot's work are singled out: his dynamic understanding of the process of historical production and the corollary formulation of the overlapping capacities in which people participate in it (as agents, actors, and subjects) and his emphasis on the importance of expanding scholarly views of the field of historical production.
\end{abstract}

Keywords Spain · Historical memory· Railways $\cdot$ Engine drivers $\cdot$ Labor organizing $\cdot$ Generation

"Our way of doing unionism had nothing to do with what the class unions were doing; we were much more bellicose", recalls Juan Oliver Barranco, the first secretary of Sindicato Español de Maquinistas y Ayudantes Ferroviarios (SEMAF-Spanish Train Drivers' and Railway Assistants' Union) with regard to the early years of the union (Bias 2006:8). The history of the combative attitude, often reclaimed as an identity marker by union representatives, is a history of belligerence that set SEMAF not only apart from the class unions but also against them. Formed in 1986, SEMAF is, relative to advantages secured for its members, the most powerful union in the railways and, throughout its existence, the only grade union represented in the works council of the Spanish railway company. The recent history of the engine drivers in the Spanish railways cannot be divorced from the history of their most

Natalia Buier

buier@eth.mpg.de

1 Max Planck Institute for Social Anthropology, Advokatenweg 36, 06114 Halle (Saale), Germany 
powerful organizational expression; neither can the history of SEMAF be told without understanding the transformation of train driving as a profession. But, crucially for the argument of this article, understanding the forms of struggle of the engine drivers also requires careful scrutiny of the specific historical representations that workers themselves employ in order to make sense of this history of combativeness. ${ }^{1}$

In this article, I explore the relationship between a particular form of labor politics and representations of the past. The article takes up a recent concern with historical memory in the anthropology of class and furthers it in three overlapping ways: (1) through the presentation and analysis of a case of workers' militancy that shows the importance of historical memory for labor politics (2) by building a case for specific theoretical tools that can deepen the anthropological conversation about labor and historical memory (3) through expanding the conversation about the political implications of theoretical and epistemological choices. Put otherwise, in relationship to the anthropology of class and memory, the aim of this article is to expand and deepen its empirical repertoire, propose a possible way of strengthening its tool kit, and contribute to the conversation about the political implications of a certain form of theoretical praxis. I do this, concretely, by showing how a certain militant particularism, that of the organized engine drivers, is made possible by a specific reading of the past: the generational reading. In order to do this, I rely on Michel Trouillot's conceptualization of the historical. His work, I argue, offers essential theoretical insights and fundamental political guidelines for a critical anthropology of class and memory.

\section{Historical memory, class, and dispossession: overcoming the dualism of history as narrative and history as process}

The recent bourgeoning of the anthropology of class has also seen a subsidiary, but important stress on the relationship between working class politics and historical memory. The call for returning class to the core of anthropological investigation (Barber et al. 2012; Blim 2005; Carbonella and Kasmir 2014; Carrier and Kalb 2015; Lem and Barber 2010) has led some authors to raise questions about the relationship between representations of the past and modes of being political (Narotzky and Smith 2002). Although a clear research direction has not crystallized, the stress on history and memory as structuring forces of the "battlefields where struggle will be waged" (Narotzky 2011:99) traverses the anthropology of class as an undercurrent. The pursuit of new ways of linking social memory and class has been expressed as a call to treat representations of the past as "historically produced conflict structures" (Narotzky 2007: 412), as a suggestion to turn our attention to the "social memory of dispossession" (Kasmir and Carbonella 2008: 17) and occasionally as propaganda by the deed, when anthropologists have directly tackled the ways in which specific political imaginaries are structured by struggles over the past (Narotzky and Smith 2002, 2006). The connection between the study of contemporary processes of class formation and historical memory is not a simple juxtaposition of topics. The new anthropology of class is marked by a salient interest in processes of politicization and the embeddedness of working class political action. As such, a lot of this literature has devoted attention to the specific forms in which lived experience is translated into political imaginaries and projects (Kalb 1997; Kalb and Halmai 2011; Smith 2008).

\footnotetext{
${ }^{1}$ The material I discuss here was collected between 2012 and 2014 as part of a broader research project which addressed the post-Francoist transformation of the Spanish railways.
} 
Quite inevitably, the anthropologists looking into the experiential worlds of labor have repeatedly encountered the fact that the past matters in a dual capacity: as process and as narrative. Building on the already well-established proposition that the reconstruction of the past is never neutral and is always marked by the political confrontations of the present, anthropologists have been lead to ask how do conflicting reconstructions of the past and forms of remembering structure political presents and futures. What the recent anthropology of class brings to the widely studied problem of social memory is the insistence that the field of historical production is unevenly structured, and that differential access to the resources required for the production of the past is consequential. Ethnography is the tool with which we can uncover both the inner workings and the everyday consequences of uneven access to the means of historical representation. If the past matters, it must surely be of importance that we are differently situated in relation to our ability to impose specific readings of the past. Anthropologists are then called upon to both show the ways in which this unequal access to the means of voicing the past manifests itself and also to tease out the theoretical and political significance of conflicting engagements with the past.

But, as is usually, the case to set a task is easier than to solve it, so in spite of the clarity with which some of the questions have been formulated, enlarging the repertoire of solutions has been a slow and ambiguous process. Consequently, what I refer to as "the anthropology of class and memory" is still a set of loosely connected propositions rather than a clear research agenda. This is to a certain extent inevitable, as ultimately many of the questions raised by anthropologists of class regarding the workings of historical memory can only be answered by "the slow work of painstaking research that permits the reconstruction of the futures of the past." (Swyngedouw 2015:226). Otherwise put, the expansion of the ethnographic record is a prerequisite for further theoretical clarification. Ultimately, the case for the significance of historical memory in processes of class formation can truly be made only by ethnographically recuperating those sectors of experience where this is so. But, sharpening the theoretical tools of the anthropology of class and memory is not a linear story of progress. As I discuss at length elsewhere $(\mathrm{X})$, there are moments in the recent history of the discipline when significant advances were made in this direction, but some of those insights have been marginalized. In what follows, I turn to the problem of their recovery and concrete application in the case of SEMAF, the Spanish engine drivers' union.

\section{SEMAF and the production of history}

Somewhere in the mid-1980s, the drivers decided they were stronger by themselves, so they decided to withdraw their negotiating power from the transversal class unions. The majority of them joined SEMAF, a union designed to represent the interests of their grade. For a while, everyone feared them, company included. As the years went by, the drivers, through their union, secured expanding privileges. By the 2000s, the former enmity between management and union was a distant memory, as the union had grown close to management. However, the first signs of the balance of power being tipped in favor of management started to appear. The future of the drivers and their status as labor aristocracy appears increasingly uncertain.

If one was to reduce the story of SEMAF to a footnote, this kind of synthesis would approximate a composite picture of the various understandings of the engine drivers' union trajectory. However, what this kind of historical summary would not be able to capture or explain are the conditions under which a certain form of unionism was selected among a variety of organizational possibilities and the conditions under which it got reproduced for 
more than three decades. In the following section, I take up precisely the details of this process in order to show how this model of organizing depended on specific forms of understanding the past. But before that, I turn to a brief discussion of the way in which Michel Trouillot's conceptualization of the historical process is useful for such a task.

As previously discussed, the anthropology of class and memory is characterized by an interest in understanding how differential access to the means of historical production is reflected at the level of experience. Otherwise put, how do different capacities for voicing the past structure the field of possibilities in the present? This question has been frequently taken up in the form of an analysis of the reproduction of hegemonic historical representations and attention to the way in which the history of the exploited and the subaltern is excluded from dominant representations. However, the theoretical resources that this these directions of research offer for understanding the way in which the dominated are active participants in the production of hegemonic representations are limited. Michel Trouillot's work, I argue, offers a powerful set of instruments for understanding the complex processes through which labor is coopted in the reproduction of dominant historical representations. For the purposes of the analysis presented here, two of Trouillot's insights are fundamental: first, his dynamic and processual understanding of the field of historical production. Second, his insistence on the need to overcome scholars's tendency to operate with a limited vision of the field of historical production.

Trouillot's seminal work, Silencing the Past: Power and the Production of History (1995), puts forward an incisive argument about the need to overcome the dualism of historical process and narrative, while acknowledging "both the distinction and the overlap between process and narrative"(1995:25). Most conceptualizations of the historical process, as he eloquently shows, sway either into a mechanically "realist" or naively constructivist direction. Even where the dialectical relationship of the two has been acknowledged, this has more frequently lead to an abstract concern for the nature of history rather than to a concrete focus on the process of historical production. Decidedly making a case for the latter, Trouillot proposes that any analysis of processes of historical production must approach people's participation in the historical process in three distinct capacities: as agents, or "occupants of structural positions", as actors, "in constant interface with a context", and as subjects, or "voices aware of their vocality" (1995:23). This conceptualization, I maintain, and further try to show, is useful because it allows us to reconstruct what Susana Narotzky has referred to as personal, institutional, and structural time (Narotzky 2011) and their interplay in the totality of lived experience.

Another aspect of Trouillot's conceptualization that I maintain is distinctly important for an anthropological exploration of class and memory is his stress on the need to expand our understanding of the field of historical production. Trouillot's work devotes a great deal of attention to the problems resulting from scholars' tendency to overstate the difference between emic and etic accounts, or scholarly and public discourse. But as Trouillot insists, the production of history is a multi-sited process and academic accounts are but one site, not necessarily the most important for processes of historical production. Naturally, most of the critical interventions on the topic of class and memory nominally adhere to a version or another of this proposition. However, in practice the traditional division of labor that marks ethnography has made it particularly difficult to advance in the practical exploration of this theoretical statement. The tendency has been to assume that most emic accounts are formulated at a lower level of abstraction and that the political intervention of the anthropologist should consist in formulating the connections between the particular and the universal, thus showing how locally situated subjects are implicated in broader structural processes. Differently from this approach, I argue that placing emic and etic accounts in the same dynamic field of historical production requires a rethinking of the role of the 
anthropologist. Rather than simply revealing the scaling processes that traverse particular biographies, individual, or collective, an anthropology of class and memory should force the confrontation between different ways of articulating the universal and the particular, a proposition that I will return to in the final part of the article.

In most of the remainder of this article, I take these propositions to the concrete case of SEMAF in order to show how a set of historical representations is integral to a certain model of workers' militancy and union organizing. In order to do this, I explore the ways in which the different capacities in which people participate in history overlap by looking at how railway workers are situated as agents, actors, and subjects in relationship to the recent history of Spain and the national railways. I complement this analysis with concrete instances of the production of mentions and silences and finally turn to pointing out alternative forms of connecting the past and the present.

\section{SEMAF across scales: from agents to subjects}

Formally, the history of SEMAF covers just slightly more than 30 years. Formed in 1986, the union was born amidst a wave of mobilizations that had been spearheaded by the engine drivers, whose collective power and strategic position in the railway system were central to the negotiating power of the main union confederations. The history of SEMAF begins in a year of crucial importance in the recent history of Spain. 1986 marks the formal accession of Spain to the European Community, but also the election of the second socialist government of the postFrancoist years. 1986 is also a year of outstanding importance in the recent history of the railways, since it is the year in which the decision to build the first high-speed rail (HSR) route in Spain was taken. The decision to build the Madrid-Seville line, the inauguration of which took place in 1992, was the starting point for what eventually turned into the most important Spanish infrastructural project, an exceptional HSR network. Currently, the longest HSR network in Europe, and the second largest globally, Spain's HSR network has become a synonym of Spain's trajectory of modernization in the post-Francoist era.

The history of the rise of HSR in Spain closely parallels that of SEMAF, and understanding the rise of SEMAF is also a way of shedding light on the transformations that the sociotechnical system known as HSR has produced in the lives of a collective of skilled workers. The development of HSR has been essential to the post-Francoist project of modernization, and the contradictions that are manifest in the history of SEMAF speak to the tensions that traverse the project of national modernization and European integration. Unlike most accounts that constitute the contemporary anthropological record on labor politics, this is not a story about defeat, it is a story about a powerful workers' collective that for more than three decades has seen its situation improve. It is neither a story about the successes of class politics. The contemporary anthropology of class has shown a lot of interest in understanding the contemporary shift of the working class towards right wing politics, and in this, it has managed to destabilize assumptions about a one on one correspondence between material conditions and political subjectivities (see Kalb and Halmai 2011). However, this literature is still incomplete when it comes to understanding the limitations of official unionism, and it has too often resorted to a generalistic account of the decline of organized labor. This article seeks to expand the conversation about the relationship between working class politics, class-based mobilization, and union organizing by looking at the contradictions that traverse grade unionism and showing the conditions under which it can become an instrument for the 
subversion of class politics. This, however, can only be done by reinstating workers as protagonists of their own lives, or otherwise put by assuming that the kind of politics SEMAF has made possible features engine drivers not only as agents and actors, but also as subjects.

\section{Occupants of structural positions}

SEMAF is a child of the early years of post-Francoism and as such carries with it the structural constraints of the times. For decades, the Spanish national railway company was the largest public company in Spain and at its peak employed more than 100,000 workers. The first decade of the post-Francoist history of the railways was characterized by a hegemony of the two main union confederations, $\mathrm{CCOO}$ and $\mathrm{UGT},{ }^{2}$ self-identified as class unions and aiming at collective representation of the workers. The appearance of SEMAF on the stage of union politics marked a departure from the previous institutional organization of labor politics in the post-Francoist railways and represented the appearance of grade unionism as a competitor to class unionism.

The birth of SEMAF goes back to a turbulent year in the history of the railways, one marked by a wave of mobilizations against the reorganization of the national railway company (Red Nacional de los Ferrocarriles Españoles-RENFE). The union remains, until today, a unique case of grade unionism in the Spanish railways. In 1986, the only relevant precedent of a craft union in the railways had been that of the short-lived Sindicato Independiente de Cuadros Renfe (SICRE), trying to organize technical and managerial staff that felt marginalized by the class unions (see Cayón and Cuellar 2009). SEMAF took part in the union elections for the first time in 1986, but it was not before another four years passed that it managed to secure a representative in the works council, following the 1990 elections.

The immediate precedent for the formation of the union was the dissatisfaction of a sector of the grade with their representation in the majority unions. The founders of the union believed their interests to be inadequately represented by these, at the same time that they saw their negotiating power thwarted. This is of course insufficient for explaining why such a union had not been formed before or what is it that explains its emergence at this very specific moment in time. The broader explanation has to do with both the more ample dynamic of unionism during those years as well as with dynamics internal to the company. The early 1980s mark the start of an ample process of deindustrialization in Spain and many public sector companies were the target of fierce austerity measures (for details on industrial restructuring in the 1980s see Castaño Collado 1994; Etxezarreta 1991; Ferner 1990). The cutbacks in the railway sector were somehow delayed in comparison to the rest of the public industrial sector, and the first years of the Transition were characterized by a series of cautious concessions for the railway workers, as overt confrontation was avoided by the government. By the mid-1980s, however, this had changed, as the railways too became a target for the austerity measures led by the socialist government of Felipe González. With Spain's accession to the European Community (EC), it had finally become inevitable for structural adjustment programs to incorporate the railways, a development that resulted in railway workers joining the wave of mobilizations that was sweeping through the public sector at the time. The mid1980s was also the period during which at the national level the two main union confederations started to converge.

\footnotetext{
${ }^{2}$ The two major union confederations in the Spanish railways are the same that have dominated the postFrancoist history of formal labor organizing: Comisiones Obreras (CCOO), historically affiliated with the communist party, and Unión General de Trabajadores (UGT), with ties to the socialist party.
} 
By the early 1990s, SEMAF started to consolidate its position in the landscape of railway unionism, and for more than two decades it has represented the majority of the train drivers. The restructuring of the railway company in line with the imperatives of the liberalization process initiated in the mid-2000s strengthened the position of the union. The division of RENFE into an infrastructure manager and a service provider resulted in SEMAF becoming the majority union in Renfe Operadora, the service provider company. If the memory of the early years of the union seems to be indissolubly related to its conflictive orientation, it is certain that its more recent history and the significant advances that the union has managed to secure for the group of workers it represents are also part of a history of tightening relationships with the company and increasing isolation in the union landscape. This is manifested not only in the public conflicts with the other unions but also in the union's history of negotiating separate agreements for the train drivers' collective.

\section{Actors and subjects}

As previously noticed, SEMAF's story is one of unlikely success in a context dominated by the steady decline of workers' rights and increasing weakness of the labor unions. The union's trajectory contradicts plausible predictions based on the existing analyses of the relationship between grade development and the contemporary transformations affecting the railways. Academic as well as autobiographical accounts of work on the railways and craft identity signal the erosion of the prestige once enjoyed by train drivers and the erosion of their work as a source of professional pride, with technological transformation playing a central role in the process (Gamst 1980; Edelman 2004; Strangleman 2004, 1999). Empirical investigations of engine drivers" careers confirm the pervasiveness of "the repeated claim of a contemporary loss or decline in work and employment" (Strangleman 2007:93) and its association with a destabilization of identities constructed around the meaning of work, not unlike in other industrial sectors that have undergone major reorganization processes.

The case of the Spanish train drivers' union unsettles the empirical account of the pervasiveness of the sense of loss among skilled workers in the railways and shows the conditions under which craft pride can become aligned with company interests. Available sociological accounts of the transformation of the work process and the accompanying ubiquitous sense of loss across different moments in the history of the railways do not truly prepare us for making sense of the following statement by a SEMAF official commenting on the differences between the engine drivers' union and the test of the unions in an article from the anniversary edition of Bias, a union publication:

The unquestionable fact that SEMAF, apart from being the strongest and most representative of the activity of railway transportation from its inception, holds today the title of majority union of the up until now only railway operations company, has united them (i.e. the rest of the unions), in their attempt to recover old privileges, in the search of mechanisms that would allow them a "return to the past" that would guarantee them the continuity of, their, so to speak, union activity. Union activity that, as we have always seen, and especially during the last years, consists of not doing anything and waiting to see what SEMAF obtains for our grade in order to say that they also want it, effortlessly, for the rest. (Bias 2006:21)

But, the portrayal of the rest of the unions as nostalgic rarely appears in isolation, and most of the times, it is met by a powerful restating of the recovery of the social prestige of a profession that has risen from its own ashes: 
We have evolved in a spectacular way, since nowadays the driving grade does not have to worry about extra hours' work in order to obtain a decent salary. The engine drivers' profession has dignified a lot and I believe it is a privilege to belong to an officially approved and socially recognized profession. (Bias 2006:22)

\section{The production of mentions and silences}

In what follows, I track the contemporary story of the making of the social prestige of the engine drivers' union as a specific mode of relating to the past and try to unravel the relationship it establishes with some of the highly controversial positions the union has taken throughout its existence. The first aspect I turn to are the origins of the union. The way this features in the historical representation of the union is essential to seeing how the transition from the class unions to a narrow form of grade unionism was and keeps being understood.

Inscribed in the history of the 1980 s mobilizations, the retelling of the story of the birth of the union reinforces the memory of the fighting attitude of the engine drivers as a distinct body within the workforce represented by the class unions. The train drivers recall themselves at the front of struggles but unable to better their situation. Early attempts to organize grade specific representation included the "pleno de conducción" within CCOO (an engine drivers' assembly), but this, as most of their militancy, is remembered as lost to the objectives or the inefficiency of the class unions. In the words of Miguel, engine driver and today a SEMAF representative:

A moment arrived when the driving grade said "We are in the streets, we are on the tracks all day, mobilizing. And we can't see anything improving in our social conditions, our working conditions [...] But they (i.e. CCOO and UGT) would block any proposal that could generate an internal conflict because it would have implied a greater improvement for the engine drivers against other groups. This is where it originates (i.e. SEMAF) and so we started walking. The beginnings were very tough because the big unions were putting pressure on the company to not even receive us. The possibility to reach agreements was remote and we had to gain a mobilization basis.

But, recollections of the early years of the union are also indissolubly linked to the experience of being an engine driver in the 1980s. The long working hours and the poor working conditions, as in the above description, are remembered as the notorious hardships suffered by a group of workers with an important degree of responsibility. The memory of those years as challenging years for the profession cuts across union affiliation, and resurfaces in the recollections of drivers not affiliated with SEMAF, and is also found in the contemporaneous press or workers' publications. This, of course, is often times described as a condition stemming from the general condition of the railways in an era of cutbacks and underinvestment. However, in the history of SEMAF, the driver emerges as the outstanding victim of a condition against which they were actively fighting, as opposed to the compromised class unions.

\section{Formulas of erasure and banalization}

"Effective silencing does not require a conspiracy", Trouillot remarks (1995:106), and in the narrative formulas of SEMAF, we can observe the interplay of mentions and silences that makes possible a seemingly triumphant account. For the rest of the unions, the implementation of the single driver policy represented a historical defeat of the workers (in a way which resonates with 
the similar events described by Ferner (1990) for the British Railways). Similarly, the arrival of HSR has been broadly (if sometimes just nominally) opposed by the class unions, as it represents the culmination of a model which would see the definitive establishment of the functioning of the railways in the service of private accumulation. But for SEMAF unionists, both the single-driver policy and the turn to HSR development are integrated into a history of constant progress and are seen as evidence of it. By looking at these cases, it can be seen how the union's ability to defend an increasingly narrow collective of workers has been reconstructed through specific erasures and formulas for the banalization of defeat.

The more recent history of the union and its achievements are described as set either against or upon the firm foundation constituted by its early years; marked by hardships, the beginnings of the union, as previously seen, were characterized and are remembered as defined by the drivers' willingness to confront the company. The establishment of the single agent features prominently among recollections about the most important achievements of the union. Concluded in 2000, it represented the suppression of the driver's assistant position. Contrary to all expectations, this is recalled as a moment when drivers, using their collective power, managed to push through a course of action favorable to their grade. They also appear as moments at which the strength of the drivers was publicly projected and their leverage was indisputably affirmed. The transition to the single driver was preceded by a series of strikes that managed to paralyze the railways nationwide. This is how Santiago remembers the 2000 strikes:

They wanted to institute the single agent and the company wanted to impose it through negotiations it had carried out with one of the unions, UGT. This led us to mobilize and there came a day when not that a train would leave the station and another wouldn't, but there came a day when none would leave. A very tense situation. We were opening the news bulletins. I remember the pope was in Spain and instead of the news bulletin opening with the pope they would start by saying that they are going to fire us, the members of the strike committee. And well, after a 40 hour meeting, or 30, I'm not sure, we reached an agreement. Yes, the last meeting must have lasted 30 hours. And there we reached an agreement important for us, we accepted the single agent but with the establishment of reasonable driving limits.

To the mythological character of the strikes speaks perhaps more than anything else the fact that the strike did not coincide with the visit of the pope. Perhaps, the juxtaposition of the coverage of the highly mediatized pope's visit to Jerusalem with headlines about the drivers' strike is what later resurfaced as the memory of the pope's visit to Spain being eclipsed (Fig. 1). What remains certain is that varied contemporaneous testimonies confirm the exceptionality of the strike, in which a large number of drivers decided not to respect the imposed minimum services, typically resorting to calling in sick. The strikes have entered not only the memory of the confrontational tradition of the union, but even at the time stood out as an affirmation of the workers' collective power in an age in which minimum services make most strikes virtually pass unnoticed ("not that a train would leave the station and another wouldn't").

The prolonged conflict between the company and the engine drivers which is retrospectively recovered as "the single agent" issue was actually a broader conflict that included gradespecific demands that ranged from bettering driving conditions to upgrading the assistant drivers to the position of driver, and which had actually started off as a conflict around the 12th Collective Agreement that involved all the unions except for UGT. The focus on the drivers' grade issues marked one of the last phases in the conflict and the decision of SEMAF to pursue grade demands rather than remain a part of the struggle for a company-wide agreement. As far 
Fig. 1 Frontpage of El País during the March 2000 strikes, featuring a headline about the railway strike and an image from the Pope's visit to Israel

\section{EL PAIS}

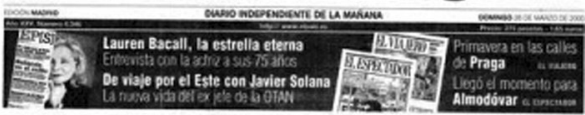

Renfe anuncia que despedirá a la cúpula sindical que dirige la huelga

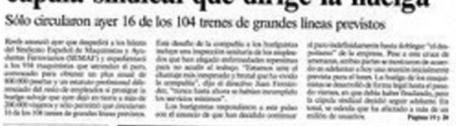

Rusia decide boy i concede meyori: absoluta al crigmático Putin
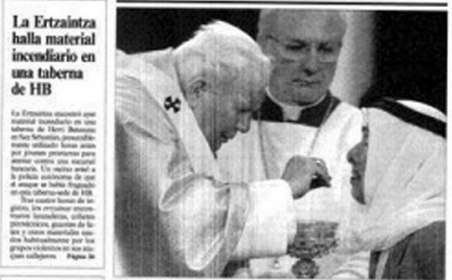

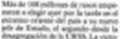

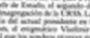

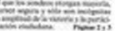
Un infiemo en nombre de Dios $-5$ omeosta arlos Iturgaiz: Major Oresa es en (a)

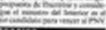
La guxtra ded pasiono E Bara gen E Papa critica la dinisibe de los cristianos de Jervsalin moritisicus: Maluga, d Mand hempon
coed Ringoyd Atkocose hand
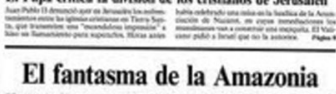

73.112

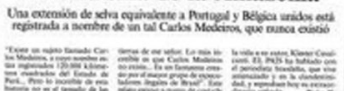

as the driving grade is concerned, the conflict ended with the incorporation of the drivers' assistants as train drivers, but with the suppression of the presence of a second driver on the train, an event remembered by many of those critical of the process as the "selling off of the driver's assistant", marking the end of the iconic team of the engine driver and the fireman, an image going back to the era of steam. But in the recollections of members and representatives of SEMAF, the event is assimilated to a continuous process of betterment of a job once carried out under distinctly worse conditions, a recollection made possible by the fact that the company traded the suppression of the position for an increase in wages and other financial incentives. It is the latter that feature prominently in SEMAF accounts, rather than the management's successful breaking of the strikers' original demands.

Another unexpected celebratory account concerns the development of Spain's high-speed rail service. Its' history intersects curiously with the image of constant evolution that dominates SEMAF members' recollections, and it features prominently in the contemporaneous accounts of the recognition of the merits of the profession and its gains in terms of social prestige. Unlike the rest of the unions, even the majority ones, SEMAF's recent history is marked by an overtly sympathetic position towards the high-speed rail project. What for the other unions has become a common slogan, "velocidad alta, no alta velocidad", 3 is a position even rhetorically removed from that of SEMAF, overtly supportive of the high-speed rail project. The testimonies of engine drivers affiliated to SEMAF reveal how the high-speed rail project, presented nationwide as bearing the renewed, expansive energy of a once again

\footnotetext{
${ }^{3}$ The expression can be roughly translated as "higher speed, not high speed", pointing to the difference between those in favor of the development of HSR and the alternative of upgrading conventional rail, supported by most of the other unions.

${ }^{0}$ https://www.youtube.com/watch?v=KbTYYap9h2o
} 
globally leading Spain, was integrated into the drivers' lives as the experience of affirmation of professional prestige. This is how Pablo, a driver on the first high-speed rail line, the MadridSeville line, remembers the early years of high-speed rail:

That which shocked me a lot, the change that took place here in Renfe, was the step to high speed rail, which yes, I did experience first-hand. This was something else. We were in Renfe for many years already. I think I was 33 when this happened...it was 22 years ago, in 1992. Back then we worked as engine drivers : a bit of freight, a bit of passenger rail, a lot of suburban rail. I had just spent two years in long-distance [...] And we moved to doing the high speed rail line and this was a terrific shock : of how to work, how to think, how to act, the safety it involved, all the involvement of the mass media at the time. This for me was an important shock. I experienced it from the beginning, from 1992. Yes, the Madrid - Seville line [...] That yes, that was important in the life of the railway worker. As a matter of fact it has marked me until this day. Here I am the « AVE boy »

What surfaces in the individual testimonies as the gain of a sense of professional worth and the radical improvement in working conditions also features as an integral part of the contemporaneous corporate image of the railway company, albeit with a different emphasis. A 2010 TV ad for RENFE ${ }^{4}$ (year of the division of the company into a service provider and an infrastructure manager) tells us, in less than a minute, the story of the rebirth of the engine driver's profession. The video opens with black and white footage of a steam engine piercing the landscape at an abnormal velocity, and as the camera shifts to the iconic driving team, the following conversation is carried out between Antonio, the troubled engine driver, and Ricardo, the disillusioned fireman:

Ricardo: "What is wrong with you, Antonio?"

Antonio: "Ricardo, you are a fireman, I am an engine driver. Your father was a fireman and mine was an engine driver..."

Ricardo: "And your grandfather and mine..."

Antonio: "And now the son says he wants to become a pilot..."

Ricardo: "Maybe he's right and this thing of ours does not have a future..."

The image fades out and the scene shifts to bucolic color scenery, with the now old fireman running in the fields towards the former fireman, Ricardo, as he shouts: "Ricardo, Ricardo, Ricardo! The grandson is going to be an engine driver!" The video closes with a scene of the two old men, dressed in suits and trench coats, admiring the passing by of a high-speed train, as the message "The train returns to being at the center of our lives" is read out.

Despite the fact that we never learn whether the son has succeeded as a pilot, nor do we understand why is it that the fireman does not cry out "I was right!" with the assistant driver's position, the last trace of the fireman's position in the actual work process, having disappeared from the occupational scheme of the railways at the time of the airing of this video, we are led to believe that a once existing professional prestige has now been restored to the point where becoming an engine driver can outdo the appeal of a career as a pilot. As a matter of fact, the power of the restitution is such that it even seems to be retrospectively projected on the careers of the former steam engine driver and fireman, who are wearing ties and suits, the memory of their painstaking lives as blue collar workers lost in an attire intimating careers as union leaders spearheading company buyouts rather than working lives spent shoveling coal.

$\overline{{ }^{4} \text { https://www.youtube.com/watch? }}=$ KbTYYap9h2o 
This form of depicting the past coincides with as much as it contradicts engine drivers' actual recollections of the past. The recovery of the lost prestige, while smoothly integrated into the narratives of decline that dominate official railway history, seems to belong almost exclusively to a realm of representation that is not anchored by the actual experience of work on the railways. Engine drivers' memories of their work lives are marked by the memory of high responsibility and the recollection of lifetime employment within the same company, but they are quite removed from the idealized, nostalgic portrayal instrumental to corporate branding. Rather, they are histories marked by the tension between a lifetime devoted to one job and the hardships and distinctly ungratifying nature of that job, applied to both work conditions and the issue of social recognition. In that sense, the typical recollection of a Spanish engine driver's early years in the company is much better approximated by a story of the discrepancy between the high level of responsibility and commitment entailed by the job and the contrasting lack of social recognition it enjoyed. What, however, does feature prominently in the union's official description as well as in the personal recollections of the drivers I have interviewed is the contemporary change in status of the engine driver. A sense of the past dominated by a sense of evolution and change, unsettlingly captured in an image from the official union publication, Bias (see Fig. 2). The image accompanies a feature article titled "We are evolving", listing the accomplishments of the union on its 25th anniversary. The article reads: "[...] Because in the decade of union freedom prior to the birth of SEMAF there were practically no advances for our grade. But since the creation of our union the transformation has been spectacular and it has entailed the recognition of the profession of engine driver as such and the profession acquiring undoubtable prestige and acknowledgment." (Bias 2011:4).

If improvements in wages are inextricably linked with the drivers' organization and their negotiating power, the betterment of work conditions is to a large extent the consequence of investments in the railways which have resulted in technological transformations which have significantly changed the nature of the work carried out by engine drivers. The transition to high-speed rail is the culmination of this, and its radical transformative power is described as follows by Pablo:

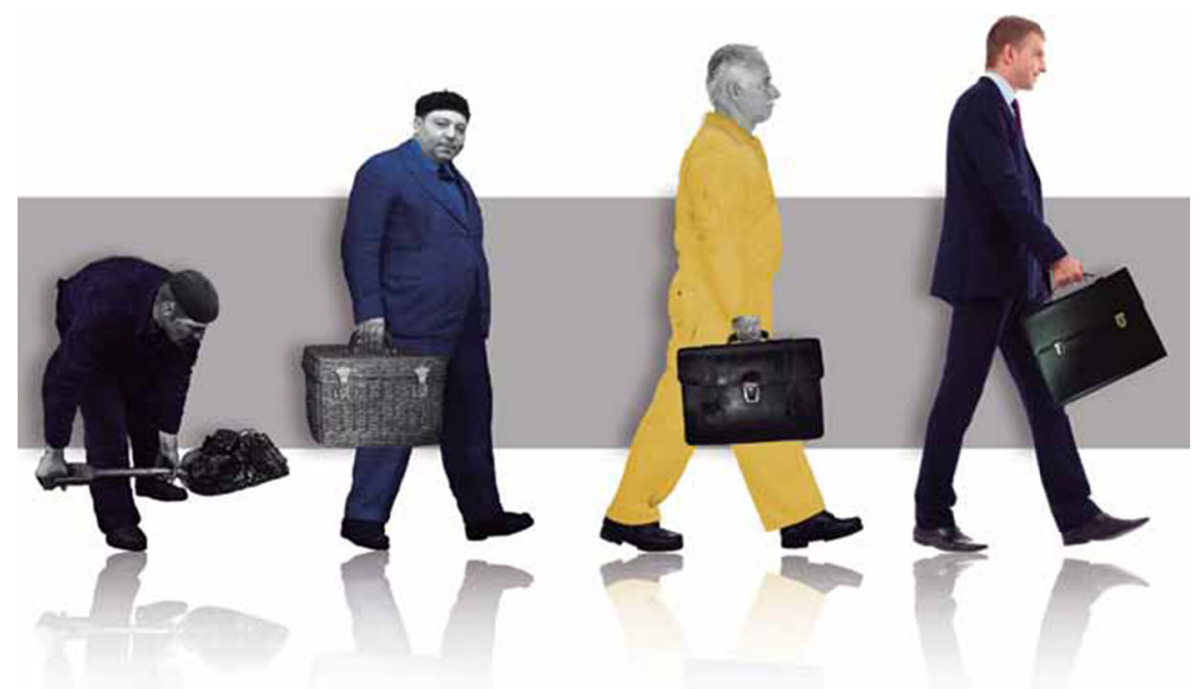

Fig. 2 Bias: "Evolucionamos" 
We had a different way of working before arriving to the AVE and from there almost a mentality change. It was a different type of work with respect to involvement in work. Something which I believe is now already getting lost. [...] You would get involved, you would come to work feeling at ease; you came very happy, you helped, you cared. In all companies what happens is more or less the same: your work begins, you check the time, you look at your watch and you get out running. In those times we didn't look at the watch. You didn't care if you finished half an hour later, even 5 hours later, you would keep working, you were doing things that you liked. This was a change that I got to understand only after some time had passed. Or well...I understood it in time. We had more training than anyone else in Renfe, we had more resources, everyone focused on us, all that help... So it was a change towards working differently. Entirely different from that which Renfe had been until then.

\section{An alternative historical synthesis}

SEMAF's uncanny story of betterment in an age in which the sense of the workers' past as loss is almost ubiquitous has not passed unnoticed in the syndical landscape nor is it missed by workers commenting on the relationship between different grades. Some accounts share the diagnosis of radical betterment and attribute it to the "egoism" or "selfishness" of drivers, a collective always narrowly following its own interest, not prone to acknowledging the importance of different types of work carried out in the railways. Others warn against the dangers of pursuing exclusively the interests of the grade, in view of a potential future need for broader workers' solidarity. Most interestingly, though, a range of accounts fundamentally unsettles the history of progressive betterment by anchoring it in a fundamentally different historical explanation. I repeatedly came across this reading of the recent history of the railways in my conversations with Confederación General del Trabajo (CGT) representatives and affiliates, an anarchosyndicalist organization that is the third major union confederation in the railways. These accounts made cautionary tales in at least two important regards: on the one hand, they qualified "betterment" and rendered the idea of "improvement" contentious. On the other hand, they were stories that unsettled the identity between SEMAF and the driving grade, speaking of divisions where otherwise unity was assumed. The caution, however, was seen, rather than as fulfilled prediction, as foresight informed by the cyclical nature of the railways' history. For most of those I talked to the developments were perfectly expected in a scenario of the liberalized railways, a historical reality that had been previously experimented both in the distant past of the national railways as well as in their more recent international history.

Here is how Álvaro recounts the 2000 struggles and the issue of the "single agent" in relation to SEMAF, a year during which the railways section of CGT managed to increase its' representation among the driving grade:

In the beginning they were together with everyone else because they had understood at a given moment that the struggle is either one of all or there are no possibilities for support; which means that if you follow alone that which is yours alone no one will support you. But in that moment they signed an agreement which was the single driving agent, which is to say that there was a change from having two engine drivers to having just one. With which they were abandoning some of the engine drivers. There were drivers, for example in freight, for whom the working conditions worsened significantly, although they would have been paid more. [...] They created a double wage scale in 
which the old ones, the old engine drivers have some conditions which the newcomers don't $[. .$.$] In the end what they create, and I think here the company completely defeats$ them, is that they are obliged to accept that not all drivers are equal. Not all railway workers are equal, that was something they were already proposing, and now it's a bit part of their union paradigm, but here that which they accept is that not even all drivers are equal. You have engine drivers of the first, second, and third category, and those who have entered recently are almost not considered engine drivers.

That this defeat seems to have been easily integrated in the triumphant account of SEMAF's achievements is not merely the spinoff of deceitful union propaganda. Interviews with SEMAF representatives and affiliates confirm the pervasiveness of the sense of progress. In contrast to this already sketched dominant sense of the past, here is how a young, CGT-affiliated driver thinks of the more recent developments regarding the appeal of high-speed rail:

By now it's not that beautiful. Now it's so generalized. Lately you have people who want to leave the AVE (Alta Velocidad Española-Spanish High Speed Rail). "I don't care about the AVE..." Also, work on the AVE implies many hours far away and you have to sleep a lot away. It's not a journey on suburban rail [...] And then you reach a certain age and you ask yourself "What am I doing here? Yes, yes, I look at my silk tie but I'm the unlucky one...so little by little this also wears you out [...] So little by little people started leaving. Lately you have a lot of people from the AVE who have asked to move to Mostoles Lesoto which is suburban rail. "I'm going to go with my t-shirt and my pants [...]"

The narratives do confirm the prominence of the role once played by the high-speed rail in the lives of the engine drivers. From anecdotes about the increase in the number of cars registered in Avila ${ }^{5}$ to those about the symbolic weight of changing the title of the high-speed rail drivers to that of "trainmaster" (jefe de tren), these alternative recollections speak about working on the high-speed rail as an unprecedented source of distinction in the lives of engine drivers. That which they unsettle, though, is the durability and the history of linear progress. Rather, they feature as an episode in an overall cyclical history of the railways, one which confirms the erosion of work standards and the vulnerability of a divided workforce. Or, as in the interview I carried out with Álvaro and David, of the mirage that made workers believe that they could be inheritors of the prestige of the high-speed rail:

Álvaro: they insisted that they would put the symbol of AVE, that they would put the three lines on the sleeve because that way they would look like...

David: ...like captains.

Álvaro: yes, captains, or doormen at a luxury hotel.

David: [...] so I think little by little it has been going down (i.e., the appeal of high speed rail), it is not as penetrating as it used to be.

Álvaro: in the beginning they were pilots, and now they are Easyjet pilots.

David: definitely.

These accounts, then, also speak to the importance of the same events that feature prominently in the recollections of SEMAF-affiliated drivers. Even more importantly, these transformations are clearly identified as a source of professional prestige in the life of the

\footnotetext{
${ }^{5}$ The license plate for Avila is $\mathrm{AV}$, which can also stand for alta velocidad (high speed). According to some of my informants in the first years after the inauguration of HSR, HSR engine drivers from the region of Madrid would register their cars in Avila as a form of identification.
} 
drivers. However, their exposure as a company smoke screen is seen as imminent. As soon as the necessities of privatization will unravel the full extent of the planned transformation, the trainmasters will again find themselves threatened as workers, a status which they were lead to believe they had elevated themselves from.

\section{To feel like a railway worker, to remember as a generation}

The previous understandings of the recent transformations affecting the engine drivers, when measured against the celebratory tone of the SEMAF-related accounts, leave behind an image of the train driver duped by the company to buy into a never meant to be fulfilled promise, the socialization of the advances of the post-Francoist railway modernization project. The different account of the recent history of transformations and the unsettling of the optimistic narrative of grade development is usually joined by some kind of diagnosis of drivers having been maneuvered into lesser deals, as against their expectations. But a closer look at the way SEMAF and affiliated engine drivers understand their historical positioning yields a quite different image, one in which drivers seem to be aware of the uncertain futures of future generations of drivers, both in terms of the nature of the work they will carry out as well as the overall work experience in relationship to the liberalized company:

Those of us, the colleagues that have been here ever since, we go on believing, inwardly, that we are working in the same company. This weekend, no, two weeks ago, we were together in the place where we started ; it was our $40^{\text {th }}$ reunion. We go on thinking that we are the same company, but inwardly we know that it is not, but we act as if it were. We keep on saying that we are railway workers (ferroviarios). And our way of expressing ourselves, this has not been broken. The perspectives there are...Well, the perspectives for those who will be staying here... We are going to leave from here with the perspective that it has been the same company. Nevertheless, we know that this is going to be different, that it's not going to be the same; that more people will enter to work, more companies. The railway will diversify a lot [...] One will not get along with the other. The same that has happened with the airports will happen here. And then yes, it will be a shock, because before we were indeed a family. But I don't think this is bad or good. As I will not be here to witness it (laughs). My perspective is that I will be retiring in three, four years. So I do not have much left.

This recollection, far from pointing in the direction of naiveté as tipping the scale in favor of certain decisions, brings to the foreground the role played by drivers acting as a generation in relationship to grade organizing. The attempts to resolve the tension between the celebratory sense of the recent past and the skepticism expressed in relation to the near future through properties immanent to the grade or the reduction of the conflict to a synchronic intercompany balance of forces prove equally limiting. The attribution of drivers' behavior to the nature of their work is widespread, among workers as well as analysts of work in the railways (Gamst 1980; Edelman 2004). The first ranges from simple characterizations of engine drivers as "selfish" or "egoist" to more elaborate accounts that match if not surpass the insights provided by sociologists or anthropologists of work pointing out the individualization of the drivers as a result of the work process (Gago González 2006; Edelman 2004; Gamst 1980).

The case of SEMAF, though, points to the insufficiency of this range of explanations. As seen in Álvaro's account, the support of the union among drivers has not been constant, and the "single agent" issue revealed the fragility of the consensus within the grade, as certain drivers felt 
marginalized or betrayed by the official union line. As seen in Pablo's account, a vision of the grimness of the future and the celebration of the continuous progress in the work of the driver are not exclusive, nor are the two represented, retrospectively, as a sequence in which later developments force one to reevaluate one's previous experience. What seems to be recurrent in the recollections of the SEMAF-affiliated drivers is their coexistence. Rather than looking for the explanation which would undo this as an apparent contradiction, my interviews suggest that this is foundational for the drivers "who feel and act one way, but know otherwise..."

This tension is the expression of the experience of a generation and of the force of the generation as a structuring principle of the lived experience of the drivers. The peculiarities of the sense of the past of SEMAF-affiliated drivers are indissolubly related not only to the generation understood as shared experience, but also to the generation as a dominant temporal frame that structures accounts of the past. The evolution of employment in RENFE overlaps with the history of the union in a profound way. While this is currently changing, until recently, the workforce in the Spanish state railways was essentially a rapidly aging population. Company hirings in Renfe were essentially stalled during the 1990s, so that when the process of hiring in RENFE was reopened, this essentially resulted in a situation in which those recently arrived to the company were separated by most workers by typically more than 15 year age difference, matched by a difference in seniority, with most of the older workers having spent all their working years as railway employees. The majority of the SEMAFaffiliated drivers belong to the older age group, an effect amplified by grade specific selection procedures. The sense of the generation is strengthened by the homogeneity of their professional trajectories. Most of the SEMAF-affiliated drivers still conform to the stereotypical image of the driver as a life-long railway employee, whose work experience is essentially tied to one company. Many of the drivers also share the experience of a training process essentially belonging to the Francoist railways, that of entry to RENFE through the military, a selection procedure abolished in the late 1970s. The unity of these professional trajectories includes the shared experience of being a driver through a decade in which the railways had been singled out as an antiquated, reactionary institution, the arrival of the sweeping high-speed rail project and the putting into place of the new organizational structure required by the privatization plans. My research with militants from the other railway unions reveals that the generational identification is distinctly strong in the case of SEMAF unionists and union members, and that this is constantly reinforced through the dominant discourses at the union level and autonomous social rituals, such as the frequent reunions of graduates of the same cohort.

Recent analysis of the Spanish context has provided useful insights into the ways in which sociological metanarratives about middle classness have contributed to marginalizing alternative accounts of the recent past and the way in which uniquely positioned generational units have formulated alternative, if marginalized accounts of the Transition (Faber et al. 2011; Labrador Méndez 2014; Sánchez León 2014). The analysis of SEMAF that I undertake here acknowledges the importance of recuperating non-hegemonic representations, but parts with the static representation of working class memory that some of this analysis has remained constrained by. Constructing hegemonic and alternative discourses as dichotomously opposed can prevent us from understanding the way in which the reproduction of dominant discourses operates through the cooptation of groups whose experience lends itself, potentially, to different historical interpretations. The analysis of the celebratory account that informs the engine drivers'model of unionism is revealed, on closer scrutiny, to depend not on the simple interiorization of dominant historical narratives but on the possibility of fixing political imaginaries and forms of organizing through a generational reading. To this end, Abrams' 
insistence that age-sets are differentially situated in relation to the possibility of "giving historical experience historical significance" (Abrams 1994[1982] is extremely helpful but remains an underdeveloped heuristic tool. What the anthropology of class and memory, with its stress on understanding the "social memory of dispossession" (Kasmir and Carbonella 2008:17) adds to an account informed by Abrams' reflections is an insistence that the reconstruction of history by a generation or a generational unit is simultaneously the reconstruction of history as a generational reading. Formulated in terms of a research agenda, this becomes then the problem of how to complement a history of social representations of the recent past and their political effects (Faber et al. 2011; Sánchez León 2014; Izquierdo Martín and Sánchez León 2008) with an anthropology of historical representations.

\section{Conclusion: from the unthinkable to accepted discourse}

"When reality does not coincide with deeply held beliefs, human beings tend to phrase interpretations that force reality within the scope of these beliefs. They devise formulas to repress the unthinkable and to bring it back within the realm of accepted discourse" (Trouillot 1995:72). Michel Trouillot's words echo the type of historical work that I have tried to show makes possible understanding the engine drivers' post-Francoist trajectory as a history of constant betterment. Rather than simply viewing them as class traitors or incompletely politicized workers maneuvered into acting against their own interest, I have argued that what the case of SEMAF shows is that the recasting of history as generational history allows for the integration of contradictory developments into a single historical synthesis. This synthesis remains one that is obtained through the exclusion of alternative ways of connecting the past to the present, as revealed by the comparison with the alternative historical account of CGT members. The generational reading is, the argument goes, the formula for bringing the unthinkable into the realm of accepted discourse, that which makes possible the selfunderstanding of the workers not as class traitors but as self-affirming laborers seeking recognition for their own work.

In a moving account of the contradictions entailed by working class politics in relationship to a socialist politics of emancipation, David Harvey (1996) offers a penetrating reading of the tensions that arise from efforts to connect particular struggles to universalistic claims. This is a concern that he shares with Raymond Williams, whose life-long work is traversed by a concern for the possibility to ground (or free) emancipatory politics into the type of solidarities that arise from embeddedness into place, a concern which goes well beyond his coining of the term "militant particularism". Williams' profound treatment of the "battle between different levels of abstractions" remains, as also seen in David Harvey's brilliant application of it, an invaluable tool for overcoming the lingering legacy of camouflaged notions of false consciousness. The first to feel and understand exploitation, Williams and Harvey remind us, are those who immediately experience it: "It is no use simply saying to South Wales miners that all around them is an ecological disaster. They already know. They live in it. They have lived in it for generations. They carry it with them in their lungs." (Williams 1995:51). What David Harvey adds to Williams' reading is a careful treatment of the dangers of falling back on locally produced accounts as a repository of political conclusions. In my reading, what Harvey seems to suggest is that what is always at stake is to understand the specific forms in which the particular and the universal are connected in given struggles in order to determine the degree to which they hinder or advance emancipatory politics. "The battle between different levels of 
abstractions" is never determined in advance, but is an open-ended struggle in which academic forms of political praxis coexist alongside others.

This preoccupation that has been at the center of the intellectual praxis of both Raymond Williams and David Harvey is one that has left its legacy in the anthropology of class. The mediation between workers' embeddedness in place, time, and nature and political imaginaries has been central to the new anthropology of class. It has lead anthropologists to reject liberal moralism as well as paternalistic populism in relation to working class politics. My analysis of SEMAF is inspired by this legacy and seeks to advance discussions in the anthropology of class about the role of historical memory as a mediating force. Political projects, I argue, following Trouillot, are historical forms of representation and self-representation. Trouillot's insistence that persons always participate in history not only as agents and actors but also as subjects has special political implications for the practice of a critical ethnography. To treat workers as "voices aware of their vocality" means to assume that a working class politics, even when aligned with dominant interests, exhibits its own forms of connecting the particular and the universal, or situating experience in relation to broader political projects. In the case of SEMAF, I have tried to show that a generational framing plays a special role in keeping together the contradictions that traverse the history of grade unionism. The first step for a critical anthropology of class and memory is not to abstract from local conditions on behalf of participants in history, but to understand the way in which participants in history do their own work of abstraction based on their multiple forms of embeddedness.

Acknowledgements This article was made possible by my stay at two different institutions. The writing was completed at the Max Planck Institute for Social Anthropology, while the initial research took shape during my stay at the department of Sociology and Social Anthropology of the Central European University. Friends and colleagues at both institutions have provided invaluable advice and suggestions for bettering it. I am fortunate enough for that list to be long enough to make it virtually impossible to name everyone. Special thanks go out to all those who have generously shared their time and knowledge with me during the fieldwork phase. I must thank Don Kalb, Susana Narotzky and Viola Zentai for their overall support of the project from which this is just a small part, it would not exist the way it does absent their encouragement in all its forms. The initial research was made possible by the funding I received through a Wenner Gren dissertation fieldwork grant. Several anonymous reviewers have provided excellent advice for improving the article, much of which is also reflected in its final form.

Funding Open access funding provided by Max Planck Society. This study was funded by a Wenner-Gren Dissertation Fieldwork Grant (grant no. 8638).

\section{Compliance with ethical standards}

Conflict of interest The author declares that she has no conflict of interest.

Open Access This article is distributed under the terms of the Creative Commons Attribution 4.0 International License (http:/creativecommons.org/licenses/by/4.0/), which permits unrestricted use, distribution, and reproduction in any medium, provided you give appropriate credit to the original author(s) and the source, provide a link to the Creative Commons license, and indicate if changes were made.

\section{References}

Abrams, Philip. 1994. [1982]. Historical Sociology, 227-299. Ithaca: Cornell University Press. Barber, Pauline Gardiner, Belinda Leach, and Winnie Lem. 2012. Confronting capital. New York: Routledge. Blim, Michael. 2005. Equality and economy. Walnut Creek: AltaMira Press. 
Carbonella, August, and Sharry Kasmir. 2014. Introduction: Toward a global anthropology of labor. In Blood and Fire, ed. Sharryn Kasmir and August Carbonella, 1-29. New York: Berghahn books.

Carrier, James G., and Don Kalb. 2015. Anthropologies of Class. Cambridge: Cambridge University Press.

Castaño Collado, Cecilia. 1994. Tecnología, empleo y trabajo en España. Madrid: Alianza Editorial.

Cayón, García Francisco and Domingo Cuellar. 2009. "Sindicalismo y negociación colectiva en la España democrática: el caso de Renfe." Working Papers in Economic History.

Edelman, Birgitta. 2004. Brothers or Mates? Identity and Trust in Two Railway Trades. Anthropology of Work Review 24 (3-4): 3-14.

Etxezarreta, Miren. 1991. Introducción: La economía política del proceso de acumulación. In La reestructuración del capitalismo en España, 1970-1990, coord. Etxezarreta, M., 29-130. Barcelona: Icaria.

Faber, Sebastiaan, Pablo Sánchez León, and Jesús Izquierdo Martín. 2011. El poder de contar y el paraíso perdido. Polémicas mediáticas y construcción colectiva de la memoria en España. Política y sociedad 48 (3): 463-480.

Ferner, Anthony. 1990. El Estado y las relaciones laborales en la empresa pública: un estudio comparado de Renfe y British Railways. Madrid: Ministerio de Trabajo y Seguridad Social.

Gago González, José María. 2006. “Aproximación a la historia social: el trabajo y vida cotidiana de los ferroviarios de Movimiento y Tracción en la RENFE. Una historia oral." IV Congreso de Historia Ferroviaria: Málaga, September 20-22.

Gamst, Frederick G. 1980. Hoghead: Industrial Ethnology of the Locomotive Engineer. Rineheart and Winston: Holt.

Harvey, David. 1996. Militant particularism and global ambition. In Justice, Nature and the Geography of Difference, 19-45. Cambridge: Blackwell.

Izquierdo Martín, Jesús, and Sánchez León, Pablo. 2008. El (débil) desafío de la memoria. Minerva: Revista del Círculo de Bellas Artes 8: 42-44.

Kalb, Don. 1997. Expanding Class: power and everyday politics in industrial communities, The Netherlands, 1850-1950. Durham: Duke University Press.

Kalb, Don, and Gábor Halmai, eds. 2011. Headlines of Nation, Subtexts of Class: Working Class Populism and the Return of the Repressed in Neoliberal Europe. Oxford: Berghahn Books.

Kasmir, Sharryn, and August Carbonella. 2008. Dispossession and the anthropology of labor. Critique of Anthropology 28 (1): 5-25.

Labrador Méndez, Germán. 2014. The cannibal wave: the cultural logic of Spain's temporality of crisis (revolution, biopolitics, hunger and memory). Journal of Spanish Cultural Studies 15 (1-2): 241-271.

Lem, Winnie, and Pauline Barber, eds. 2010. Class, Contention, and a World in Motion. New York: Berghahn Books.

na. 2006. Nuestros secretarios generales: Juan Oliver Barranco. In Bias: boletin informativo de los afiliados a SEMAF, Especial XX Aniversario, 8-9. Available online at https://www.semaf.org/adm/sys_imps.php?ec= $\& p w=60 d d e c a d a 381$ ece8acc1666e189f6f21. Accessed 4 May 2018.

na. 2011. Evolucionamos. Bias: Boletin informativo de los afiliados a SEMAF. 8: 4-15. Available online at: https://www.semaf.org/adm/sys_imps.php?ec=\&pw=0c082165ffa3a06c597760f64611563f. Accessed 4 May 2018.

Narotzky, Susana. 2007. A Cargo del Futuro - Between history and memory: An account of the 'fratricidal' conflict during revolution and war in Spain. Critique of Anthropology 27 (4): 411-429.

Narotzky, Susana. 2011. Memories of conflict and present-day struggles in Europe: New tensions between corporatism, class, and social movements. Identities: Global Studies in Culture and Power 18 (2): 97-112.

Narotzky, Susana, and Smith, Gavin. 2002. 'Being Politico' in Spain: An Ethnographic Account of Memories, Silences, and Public Politics. History \& Memory 14 (1-2): 189-228.

Narotzky, Susana, and Gavin A. Smith. 2006. Immediate Struggles: People, Power and Place in Rural Spain. Berkeley: University of California Press.

Sánchez León, Pablo. 2014. Desclasamiento y desencanto. La representación de las clases medias como eje de una relectura generacional de la transición española. Kamchatka 4: 63-99.

Smith, Gavin. 2008. Formal culture, practical sense and the structures of fear in Spain. Anthropologica 50 (1): 279-288.

Strangleman, Tim. 1999. The nostalgia of organisations and the organisation of nostalgia: Past and present in contemporary railway industry. Sociology 33 (4): 725-746.

Strangleman, Tim. 2004. Work Identity at the End of the Line? Privatisation and Culture Change in the UK Railway Industry. Basingstoke: Palgrave Macmillan.

Strangleman, Tim. 2007. The nostalgia for permanence at work? The end of work and its commentators. The Sociological Review 55 (1): 81-103.

Swyngedouw, Erik. 2015. Liquid Power: Contested Hydro-Modernities in Twentieth-Century Spain. Cambridge: MIT Press.

Trouillot, Michel-Rolph. 1995. Silencing the Past: Power and the Production of History. Boston: Beacon Press. Williams, Raymond. 1995. Socialism and ecology. Capitalism, Nature, Socialism 6 (1): 41-57. 